\title{
Decentralisation in developing countries: preconditions for successful implementation
}

\section{Commonwealth Journal of Local Governance \\ Issue 15: June 2014}

http://epress.lib.uts.edu.au/ojs/index.php/cjlg

\author{
Yasin Olum \\ School of Social Sciences \\ Department of Political Science and Public Administration \\ Makerere University
}

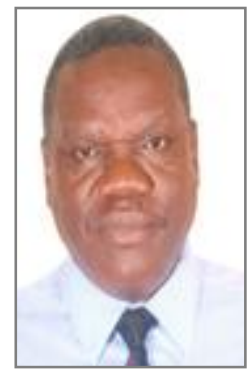

\section{Abstract}

Decentralisation has been implemented and is being implemented in many developing countries without much success. Although several unique factors inhibit the implementation of decentralisation in individual countries, the paper argues that there are six pre-conditions that these countries should fulfill before decentralisation can be successfully implemented. These preconditions are: institutional mechanisms; creation of spaces for participation; political will and civil will; capacity development at the local level; careful implementation; and democratic governance.

\section{Introduction}

Decentralisation has become a strategic policy for governmental restructuring in many developing countries. The aim of decentralisation is to re-design the governmental system in such a way that it can deliver services efficiently and effectively to the citizenry. However, the failure to take several pre-conditions into account has led to glaring failures. Before discussing these pre-conditions, it is important to underscore the fact that there are misunderstandings about what decentralisation means.

Thus, given the plethora of definitions surrounding the meaning of 'decentralisation', Leonard (1982) asserts that a single universally applicable typology of the concept is impossible. This paper therefore conceives "decentralisation" as the process through which the central government transfers its powers, functions, responsibility and finances, or decision-making power to other entities away from the centre to either lower levels of government, or dispersed central state agencies, or the private sector (Olum 2010: 2). Its main assumption is that through strengthening local institutions, local administration and service delivery can be enhanced. 
This paper argues that in order for decentralisation to be successfully implemented, the following preconditions should exist: institutional mechanisms for decentralized management should be carefully crafted, spaces for citizens' participation should be created, there has to exist political will and civil will, capacity development at the local level should be carried out, decentralisation should be carefully implemented, and democratic governance should be embedded. Before discussing these preconditions, it is imperative to trace briefly the acclaimed benefits of decentralisation.

\section{Benefits of decentralisation}

There are three perspectives regarding the benefits of decentralisation, namely: developmentalist, democratizing and centralist. The developmentalists, including the mainstream development donors, support the implementation of decentralisation because it will: bring government closer to the people; improve service delivery; educate people to become full citizens; facilitate local participation especially of the poor and thus allow government to better understand the people's needs; improve public policy design; reduce conflict by helping people to accept government decisions; socially integrate the community; and make local economies more prosperous and more equitable.

The democratizers argue that decentralisation: enhances greater citizen input in governance by strengthening both local elites and the central state; opens the way for popular participation in making decisions about policy design and implementation; and yields higher levels of government responsiveness, honesty, legitimacy, and tolerance among citizens because local officials have better knowledge of local conditions than central government officials and are thus better positioned to respond to local tastes and preferences (Burki et. al. 1999: 22).

The centralists argue that decentralisation transfers social conflicts, resources, and responsibilities to the local level where there is greater political inequality. However, they note that decentralisation reinforces relationships of subordination and pulverisation of the relative strength of subaltern actors. In addition, they argue that corruption and clientelism are more prevalent at the local level, making participation unattractive to many citizens as well as making participation itself undemocratic. Finally, they note that decentralisation impairs development because local governments are less technically capable than central government because the state loses regulatory capacity and fiscal control. The difficulty of finding strong and consistent evidence of direct causal linkages between decentralisation and many of the acclaimed benefits suggests that decentralisation can be instrumental in promoting development and good governance but it is not a panacea or an end in itself. In short, decentralisation has its own political dynamics and is by no means a universal 'good' (Barkan and Chege 1989). Thus, if the acclaimed benefits of decentralisation are to be achieved, developing countries should take into account a number of pre-conditions before implementing it. This is the subject of the next discussions. 


\section{Institutional mechanism}

Institutional arrangement is an important factor in the successful implementation of decentralisation (Litvack et. al. 1998: 7-8; Mutahaba 1991: 87-90; Steffensen et. al. 2004). The decentralisation of political power within states requires the creation of decision-making institutions which are elected and appointed (Smith 1985: 122). Rhodes (1995: 46) sees political institutions as 'instrumentalities.' He notes that the state is a human grouping in which rules a certain power-relationship between its individual and associated political institutions, which cover state organisation (including democracy), separation of powers, centre-local relations, and federalism.

Therefore, the broad mechanism for citizen input in political institutions is critical in the design of decentralisation policy. The institutionalized channels for citizens' engagement in decentralisation and the ability of the citizens to use them are two critical factors which should be taken into account as design parameters for decentralisation programs in any country. Indeed, local government institutions provide the opportunity for effective citizens' participation (Ali and Ali 1985: 298).

However, the types of institutional mechanisms that are created in the specific national environment can only be developed over a long period of time. Legislation is important in establishing the institutional framework for citizen participation. The new spaces for citizen input, written into organic laws should be put into practice, and not manipulated as frequently happens in developing countries, by political leaders or technocrats for patronage, or private interest purposes.

The institutional channels through which decentralised development activity occur are of different kinds (Uphoff 1985: 48-58). Three basic types of institutions are identifiable that also apply to developing countries: quasi-governmental institutions where the authority and other resources of the state are involved, either directly or by delegation; membership or self-help institutions where people have joined together to advance their interests through collective action; and private or quasi-private institutions where decisions can be made by owners on a for-profit basis, or by patrons and contributors on a charitable basis. These three types of institutions can be divided into local level sets of institutions, namely; local administration (bureaucratic), local government (forum for political representation), membership organisations, co-operatives, service organisations, and private businesses. These distinctions are crucial for evaluating possibilities for successful implementation of decentralisation. However, in developing countries these institutions are largely weak. 
In developing countries local institutions are largely used in illegitimate ways and are of minimal consequence to the people's lives because they do not engage them in governance. In fact, decentralized institutions are constructed in such a way that they are easily controlled, manipulated, and exploited by more advantaged sections of the elite and the local community. Some governments, therefore, do not adopt strategies that promote institutionalized collaboration among state and nonstate actors in identifying, analyzing and addressing approaches to ensure the success of decentralisation. Yet reciprocating "linkages," rather than autonomy for local institutions, are critical in providing more productive relationships for both center and localities.

Lastly, the decentralized institutional frameworks in developing countries that are constructed do not create a significant impact on its efficacy as a tool for engagement. In fact, the institutions and structures through which responsibilities, power and authority are transferred to local governments should have substantive representativity. Also, for local democracy to prevail, clear responsibilities should be defined for the representatives. In other words, decentralisation should neither maintain nor further "ongoing legislative apartheid" by reinforcing the power of unrepresentative local leaders. Indeed, the more resources, responsibilities, and decision-making authority are transferred downwards, the greater the likelihood of institutionalizing participation because local governments can offer citizens benefits for their participation. However, because the decentralized institutions in developing countries are used by some representatives to advance their personal interests, they have undermined the use of resources and constrained effective participation.

\section{Creating spaces for participation}

The concept "participation" is as old as politics, but it was after the Second World War that it was extended to all spheres of life. Its modern usage came into effect during the 1960s to express what the European Economic Commission once coined "the democratic imperative." Democratic imperative is defined as the principle that "those who will be substantially affected by decisions made by social and political institutions must be involved in the making of those decisions" (Bullock et. el. 1977).

In international discussions of development policies, "participation" is frequently used to espouse a long socio-historical tradition. Local citizens' participation in the development process has to do with enhanced capacity to perceive their local needs, formulate their demands, organize to promote their legitimate interests, secure conditions for their improved livelihood and play a major role in the management of their own affairs (Olum 1989: 12). Essentially, participation means three things (Nkunika 1987; Lisk 1985; Lisk 1981)): people's involvement in decision-making process in implementing programs; people's sharing in the benefits of development programmes; and people's involvement in efforts to evaluate such programmes. 
Besides these three meanings, participation also refers to organized efforts to increase control over resources and regulative institutions in given social institutions, on the part of groups and movements of those people hitherto excluded from such control (Pearse and Stiefel 1979). In its broadest sense, participation sensitizes people to increase the receptivity and ability of rural people to respond to development programs and to encourage local initiative. Clothed in the democracy context, the history of democracy is in large part the history of development of regular and legal channels through which citizens can express their preferences and apply pressure on government to comply with these preferences. In other words, there is a need for continuous interaction between the state and citizens in a manner that combines social justice and customer focus for citizen empowerment in the dynamics of policy development. Hence, citizens assume the role of "agent" in implementing public policies which depend more on a collective change of behavior than on the legislative authority of the state.

Several measures can be taken to encourage more widespread citizens' engagement in local governments (Burki et. al. op. cit.: 32-3). Four measures will be enumerated that apply to developing countries: adopting ward or neighborhood-based electoral districts. First is the election of, say, Councilors by a ward or a neighborhood to give geographically defined interest groups an assured seat in Council and thus some prospect that their involvement in the political process will produce tangible and beneficial results. In practice, some elected Councilors have turned out to be oppressors rather than defenders of the interests of their constituents. Second is an open and unblocked electoral system for local elections. This system decreases national party control over elected officials. The electoral process in developing countries produces outcomes that are frequently contested by the losers due to several anomalies such as rigging, violence and intimidation. Third is changing the timing of subnational elections. The timing of local elections should not coincide with national elections to avoid local government elections being overshadowed, and to discourage clientelist considerations in the selection of candidates for local office. In some countries like Uganda, local elections have not only been held on the same day with national elections but have not been held at all. Fourth is the practice of multiparty politics. Under a multiparty system, political parties provide the critical connectivity between the electorate and the political system. Political parties are an essential instrument for representing political interests, aggregating demands, recruiting and socializing new candidates for office, organizing the electoral competition for power, and forming effective governments (Diamond 1997). Hence, by organizing class and other interests, political parties in developing countries are used as instruments by which the poor and marginalized groups can gain 'voice' in the formal political system (Boeninger 1991; Przeworski 1995). Party members and leaders have an incentive to get out the vote, create a presence in the community, seek out voters, and respond to voters' interests. In many African countries, however, ruling parties have suppressed the opposition parties to the extent that they cannot perform their roles effectively. 
In spite of these constraints, decentralisation relies heavily on participation to improve the allocation of services. Decentralisation should never be used for engaging the citizens to support central government's programs, directives, and hegemony - as is the case in developing countries - but as a framework for genuine popular control over decision-making processes. In many developing countries participation can at best be described as pseudo-participation because the local citizens have no significant contribution to the decision-making process. Griffith (1981: 225) cautions that "power at the local level is more concentrated, more elitist and applied more ruthlessly against the poor than at the center."

In fact, in developing countries decentralisation has been used to support central government rather than to allow for the real sharing of power and the involvement of local communities in policy decisions regarding development within their own surroundings. This is why decentralisation has largely failed to empower citizens to engage in decision-making processes so as to ensure that policies are citizen-centric, responsive and sustainable. In most developing countries the failure to engage stakeholders in decentralisation has fostered social, political and economic stability. Hence, it is important to take concrete steps such as constitutional reforms or the creation of special mechanisms, to protect minority rights and engage minority groups in participatory decision-making.

However, broad participation can be disruptive. In developing countries local electoral cycles have led to periodic fiscal indiscipline as local leaders try to attract more votes. Hence, assessing how much citizen input constrains local government's actions provides a starting point for designing decentralisation policies. Indeed, these initial conditions determine the extent to which decentralisation will increase central government's responsiveness to citizens and provide guideline for including participation-enhancing measures in decentralisation policy. Institutional structures such as regular elections, permanent public-private-partnerships and local referendums are identifiable conditions that may improve the ability of local governments to identify and act upon citizens' preferences. 


\section{Political will and civil will}

Political commitment for decentralisation is the sine-qua-non of strategy implementation (Rondinelli 1982: 43-60). Yet it is often an element that is frequently missing especially in developing countries. It is the national governments that make the rules under which local governments operate (Burki et. al. op. cit: 18). The power of sub-national interests in the national governments has a key bearing on how the intergovernmental rules are constructed and enforced. Ideally, decentralisation would devolve government functions and authority to the local level, allowing citizens to elect their representatives to manage local affairs.

This perspective typically highlights the fact that moving government closer to the people will ease the interactions and information flow between political leaders and the citizens. It has also been the struggle of democracies regarding the question of how to represent regional interests in the national government. Theoretically, this democratisation process aids in formulating a development agenda that corresponds to local needs and opportunities thus improving transparency and accountability in public service delivery.

It should be emphasized that local development does not have political color. The behavior of politicians and the local citizens towards social and economic issues will greatly affect, positively or negatively, the outcome of every locality. The constitutions and local dynamics of every country will have a lot to do with success or failure of decentralisation programs. Therefore, political leaders should expand the frontiers of democracy by encouraging greater citizen participation in political affairs of their localities and those of the nation.

However, political leadership which behaves more in a partisan manner and is non-committal to decentralisation as happens in developing countries, encourages corruption and excludes local citizens in running local governments. In the end, and acting outside the framework of the national constitution, social services are targeted at party members instead of the deserving poor. In Uganda, for example, some voters hold the ruling National Resistance Movement's (NRM) party card because it is the surest way to access social services. It ought to be noted that in some developing countries elite capture has cropped-in which has encouraged corruption and lessening of participatory governance. In the end, the democratic benefits of decentralisation have not been fully realized.

In this sense, if political leaders are to be effective they have to advocate for civic renewal. This requirement is even more so in developing countries where regimes are somewhat artificial and weak. To rid these countries of democratic deficits in their respective local governments will necessitate the creation of effective participatory institutions and active citizenry to sustain them. The more devolved the political system, and the less clientelistic and confrontational the strategy used by the political 
leadership, the greater the prospects of successful implementation of decentralisation. Unfortunately in these countries the decentralisation strategy is sometimes used in a partisan way and functional disputes have been too tense as to interfere with the implementation of decentralisation.

Similarly, like political leaders, there is a need for local citizens to demonstrate the will to participate fully in the participatory institutions so created to implement decentralisation. After all, it is the inability to integrate citizens into mainstream development and the poor performance of the state that has given birth to the call for decentralisation and good governance in developing countries. Thus, citizens are bound to de-participate in any institutional framework if they know that they are being used to advance the interests of other parties. In this sense, citizen engagement should neither conflict with representative democracy nor diminish political will. The truth is that decentralisation in developing countries has neither guaranteed more representativeness and accountability nor more democratic government at the local level. Thus failure arises because the local people are not the direct beneficiaries but a means of legitimizing elite power, mostly through patron-client networks.

This legitimisation is because developing countries portray features of neo-liberalism and elitedominated democratisation. No wonder that in most developing countries, patron-client relations between citizens, political organisations, and the state, and a paternalistic and passive political culture that have traditionally predominated have failed to disappear with the advent of decentralisation (Alvarez 1998; Nickson 1995: 267). This unhealthy situation has had to happen because the condition of citizenship in these countries has been weak, precarious, and restricted. These impediments should be broken through active citizenship. Until a new type of active citizenship emerges, anomie and rootlessness will continue to predominate to the extent that decentralisation will not achieve what it set out to do. Thus, local citizens should have the will to become actively involved only when their vital interests are at stake (Hirschman 1970). However, local democracy should not be seen as a forum for mass decision-making on all issues of public policy. Rather, it should provide a mechanism for interest groups to reach political decisions without resorting to open conflict.

Finally, citizen engagement should not be seen as a panacea to local development and local governance. Proponents of citizen engagement should, therefore, not "romanticize the citizen" (Pollitt 2007) - in fact, no one is interested in everything. What citizens care about is that they could participate if they want to and that their 'voice' would be heard if the need arises. While citizen engagement is not in conflict with representative democracy and it is no substitute for political will, an active and dynamic citizenry will be increasingly needed not because political leaders are somewhat lacking, but because the active role of citizens as players in policy formulation and policy implementation will be increasingly central to creating new public goods and services. But sound policy formulation and successful policy implementation demands the right type of capacity. 


\section{Capacity development at the local level}

One of the essential attributes of decentralisation is the capacity that is built to implement it. The nature of the administrative system or the capacity building unit that is established, the types of administrators who occupy the offices so set up, and the accompanying tools and equipment they have, will prove extremely vital in the success of any decentralisation program. An administrative system which has poorly qualified or "ghost" public personnel with inadequate experience, and hired on clientelist criteria, as pervades in many developing countries, cannot deliver successful decentralisation.

Hence, if decentralisation is to work, local administrative capacity should be such that bureaucratic requirements imposed by the centre are appropriate for local decision-makers. What this also means is that central government should have the capacity to manage local affairs. In addition, the design of intergovernmental relations should provide guidelines, resources and incentives that would lead to strong local capacity. However, local capacity is a complicated issue, and the appropriate way to improve on it may not simply be through increased training of local officials (Litvack et. al. 1998: 2728). Indeed, local capacity building should not be looked at in a top-down, supply-driven fashion. In policy terms, capacity building should precede decentralisation. There should also exist a more dynamic and demand-driven relationship between decentralisation and capacity building.

In developing countries some officials working under a decentralized system do not only lack a full grasp of what decentralisation means and do not possess the requisite skills to implement the decentralized programs, but do not co-operate with it. Instead, the functionality of the technical staff under the decentralized system has created a parallel power structure to the system itself rather than being part-and-parcel of it. Personnel operating under the decentralized system in some developing countries have created a barrier for citizens to make their input in the day-to-day administrative process thus sustaining the old administrative or bureaucratic culture.

Yet the expectation was that under decentralisation a new administrative cadre would participate in the construction of a new participatory institutional system that would embed a new democratic political culture. This perspective should have become the new "integrative-corporatist" ethics for following the rules of procedure in the new reformed decentralized institutional framework. Public officials can improve their performance when incentives such as publicly praising and rewarding good service, allowing workers to perform a variety of tasks, and most importantly, fostering trusting, collaborative relationships between public officials and their clients by providing information to citizens and encouraging them to monitor public officials and demand improvements, are instituted. 
Instead, in developing countries administrators fear the devolution of much more decision-making power to the citizens - something that usually happens as soon as decentralisation is conceived. They fear to create strong participatory programs simply because their "opponents" might capture the new public spaces. However, for the new administrative cadre to undertake their decentralized responsibilities effectively, they need the right motivational incentives, access to resources, and to have jurisdiction over important services. In this regard, there is a need for clarity on the relationship between central and local officials on all matters relating to decentralized management. This clarity is scarce in developing countries. The reality is that the new cadre of administrators who are largely responsible for policy and program implementation have failed to execute their functions mainly because of external interference especially by politicians.

Hence, the democratisation of the decentralized administrative system at regional and district levels should be motivated by three important but interrelated considerations: to give the administration a 'local look' and so reduce the gap between the administration and the citizens; the integration of the political and government structures; and rural development. State-society synergy will only occur under conditions where state agencies and civic organisations possess cooperative and trusting ties with one another. The occurrence of such synergetic relationship will produce more disciplined and better informed public agencies and, thus, more civic engagement. Synergy can be constructed if reformers in the state find innovative ways of organizing cooperative institutions and of presenting problems and interests as common to all stakeholders involved.

\section{Careful implementation}

Decentralisation cannot be successful in developing countries if it is implemented without the establishment of proper planning and accountability mechanisms. Short of these measures, decentralisation can reallocate power and resources in a way that leads to power struggles and renewed conflict, an occurrence that is counterproductive to the very essence of decentralisation. Careful implementation demands appropriate power-sharing arrangements and allocation of resources. Ayee (1994: 199-201) captures the problem associated with the implementation of decentralisation policies thus:

The ... execution of decentralisation ... is not simply one of establishing "correct" goals and procedures. Rather, policy is a kind of theory, and a gap always exists, to a greater or lesser degree between this "theory" and the world ... being explained and, optimistically, controlled by the theory... the implementation process is not seen as an evolutionary learning process... the implementation of decentralisation policies may be seen as a continuing process of modifying government structure and procedures as conditions become more and more conducive to incremental expansions in their scope and applications. 
Successful implementation of participatory programs rests on, among other factors, breadth, depth and continuity (Berry et. al. 1993: 54-61). Breadth refers to the extent to which all citizens are afforded the opportunity and encouraged to participate, and can be indicated by how many people participate and how representative they are of the population of the given area. Depth refers to the extent to which their participation actually influences policy decisions, and can be indicated by the range of decisions over which citizens have input and the degree to which that input matters - i.e., whether citizens inform, consult, implement, oversee, or decide upon policy. Continuity refers to the regularity and the duration of citizen participation programs.

There are two other key factors that are crucial in the implementation of decentralisation (Conyers 1990: 29-30). First is the nature of the special implementation machinery that is put in place. Any agency that is meant to implement decentralisation should have the authority, resources and motivation. The second set of factors is the degree of acceptability or opposition which it will generate both at the centre and local levels. Resistance in developing countries has arisen at the local level from civil servants who resent increased local political control over their activities in situations where powers are decentralized to local politicians. At the center, resistance has arisen from civil servants who are reluctant to relinquish power or authority, say, over financial control. In spite of the fact that such problems have arisen during implementation, where possible, some of them could be offset right at the design stage and spelt out in detail to avoid their recurrence at the implementation stage.

Programs, such as decentralisation, in which many people can and do participate in significant ways over a wide range of issues on a regular basis over a long period of time are more "successful" than those in which few people can or do participate in relatively trivial ways over few issues on an infrequent basis or for a short time. Kauzya (2007: 11) acknowledges that "participatory democracy which refers to how the local communities engage in the making of the decisions that concern them needs to be studied not only in respect of whether and how it is taking place but especially in the way institutions have been created to formalize its operation and sustainability." Lastly, for decentralisation to be successfully implemented, decentralized services and workload should be accompanied by the decentralisation of commensurate resources. This issue raises political and democratic concerns regarding decentralisation. 


\section{Decentralisation and deepening democratic governance}

In theory, decentralisation as a method of organizing the operation of the state resonates well with the concept of democracy. By creating conditions for citizen engagement, decentralisation is seen as being capable of deepening democracy at the local level. Prah (2004: 21) notes that:

Decentralisation provides a structural lead to the infrastructure of a democratic culture. Decentralisation permits the existence of democratic rights at the local level, at which point most Africans carry out their everyday activities. The translation of democracy to satisfy representation and voice at the most local setting, for example at the village level, empowers people at the social points in which they most need to have a say and influence. Decentralisation brings the possibility of democracy to the elementary structures of social organisation.

However, democracy ought to include effective government - a situation that is lacking in abundance in developing countries. If centralisation was a governmental arrangement that stifled creation of local democratic states, then, theoretically, decentralisation was viewed as capable of ensuring that democratic governance is established within any political system. Indeed, in liberal democracies, there is a growing concern about the quality and quantity of political participation (Blaug 1995: 52). It is arguable that participatory governance at the local level facilitates the involvement of local communities in policy decisions that affect them both directly and indirectly. Indeed, and as Shapiro (2003: 104) once observed:

No conception of democracy geared towards reducing domination can ignore the relations between the political system and the distribution of income and wealth.

Therefore, decisions that are taken in local governments should focus on solving local problems rather than to satisfy the interests of those at the helm of the local government system (Martinez-Vazquez and McNab 1997; Olum 2010: 107). One area which is central in enhancing accountability is where participatory democracy allows for the continuous involvement and open consultations of all citizens, including civil society, on important governance issues such as budgets, opportunities to raise complaints about irregularities and poor service delivery, verification of financial accounts of local governments, transparent tendering and procurement, and the monitoring and evaluation of programs, in order to promote democracy and good governance (Kiyaga-Nsubuga and Olum 2009; Kjaer and Olum 2008).

In developing countries some local governments are failing to serve as critical spaces wherein local citizens, including special interest groups, can be integrated in the decentralisation and democratic systems (Mbatha 2003: 210). It is only through integration that the local actors can shape local and national policies and service delivery in accordance with their needs. In developing countries the local government structures that percolate up to the localized geographical areas are unable to create the necessary avenues for the communities to influence government decisions and policies. Indeed, linkages between the local organisations horizontally at the local levels and vertically to the national capital should be seen as vital in making democracy substantive. 
Mbatha (Ibid: 192) notes thus:

Local government is required to be democratic, participatory and accountable, and to promote sustainable social and economic development. The constitution gives local government the power to deal with a wide range of issues, from regulating and providing services to formulating development plans... The constitution clearly gives scope for local government to act as an agent of transformation, but the reality is that localized power entrenches existing interests in social and cultural arrangements and continues to undermine the ideals of the constitution.

Thus, when designing democratic decentralisation policies five key characteristics should be met. First, constitutional policy and statutory reforms should devolve power not only to local governments but also to local communities. Second, local governments' capacities should be strengthened in terms of, finance, personnel, organisational structures, management systems, data information, facilities, and networks, among others. Third, local government accountability to citizens and central government, transparency, and responsiveness should be assured. Fourth, the role of civil society at the local and national levels (through practicing horizontal decentralisation) should be enhanced. Fifth, there is a need to show both intent and progress in improving the quality of life of the local people - i.e., enhancing local citizens' access to public goods and services.

In light of fair and regular local elections and high levels of "social capital," community cohesion and history of working together tend to enable citizens to both signal their preferences efficiently and enforce leaders' compliance with their wishes. Clearly, what is happening in developing countries is that there is no broad citizen control of their leaders thus undermining the quality of governmental action. Yet public officials who fear for their jobs are much more likely to pick better staff to carry out the day-to-day work of government. Putnam (1993) once observed that:

Those governments which were more open to constituent pressure were more successful at managing resources and creating innovative programs to distribute services effectively.

However, there are scholars beginning from Plato to Mosa, Schumpter and more recently Moynihan and Huntington who argue that too much participation leads to inefficiency, un-governability, and citizen frustration. Huntington is of the view that a surge of participatory democracy weakens government by overloading the system with demands and making it impossible to govern effectively (Berry et. al. op. cit.: 8). This weakening is why some critiques of decentralisation prefer centralisation because local politics becomes the home of corruption and clientelism rather than democratic citizenship. Furthermore, because decentralisation has sometimes had the effect of cessation, it is important to foster dialogue and reconciliation among antagonistic groups, building a shared national identity that overrides ethnic or religious cleavages. 
On another note, and viewed from a global perspective, decentralisation should not solely be at the behest of external actors, for example, World Bank, UNDP, GIZ, DFID, and CIDA, in domestic policy formulation where it is part of imposed political conditionalities attached to foreign assistance or aid (Doornbos 1999). Much as development partners can be useful in supporting decentralisation programmes in areas such as capacity-building (e.g., effective data management, planning, and empowering local communities), establishing democracy and good governance, and accountability mechanisms, this has to be within a clear policy framework to prevent the setting up of parallel structures - government on the one hand, and donors and civil society organisations, on the other - on service provision (Saasa 2000: 24-26).

If the relationship between developing countries and development partners is to be in tandem with the theory of governance, international organisations and developed countries should work with local partners rather than dictate the democratic processes if local institutions are to be nurtured based on specific local conditions. However, given the might of developed countries and their multi-national corporations, the local citizens have little legal or moral authority over them. This is why the democratic space in developing countries tends to be constructed more at the whims of foreign actors (Maathai 2009: 63).

Yet decentralisation constructed externally does sometimes lead to only episodic outcomes thus breeding deep social, economic and political challenges which are not in line with local politics and culture. Rather than taking an open-ended generalized approach to strengthening engagement in local governance processes, the project-based support from donors eventually turns into issue-based civic participation with specific need-based sectoral targets and outcomes. Newton (1995: 108) rightly observes that:

For the effective development of globalisation theory, especially with regard to issues of democracy, much more care needs to be taken in investigating issues which focus on the active role of states in furthering globalisation and the implications this has for existing 'democratic' structures.

Communities in developing countries should think of ways of preventing any potential harm that may arise from foreign interference in domestic affairs that may be illegitimate for self-governance and injurious to their stability. In the end, local communities should endeavor to acquire power to assert their claim not only on decentralisation but authority over external actors. 


\section{Conclusion}

This paper concludes that given the acclaimed benefits of decentralisation, its successful implementation has to take into account six pre-conditions, namely; the establishment of institutional mechanisms, the creation of spaces for citizens' participation, political will and civil will, capacity development at the local level, careful implementation, and democratic governance. Institutionally, since decentralisation is about transfer of political power from the centre to the localities, there is a need to design decision-making institutions that are elected and appointed through which citizens and non-state actors can engage in governance. Although broad participation can be disruptive, it is nonetheless crucial in the implementation of decentralisation because it is the means through which citizens formulate their demands, improve the allocation of resources, and plays a central role in owning the decision-making and development processes. However, without political commitment, there can be no clear strategy for implementing decentralisation. In addition, to foster active citizenship, local citizens must also show the will to participate fully in the decentralized institutions. In terms of capacity, in order to implement decentralisation successfully the right type of capacity such as the nature of the administrative system, types of administrators and the associated tools and equipment, have to exist. Thus, the center should impose bureaucratic requirements that are appropriate for local decision-makers. As regards careful implementation, if decentralisation is to be successfully implemented proper planning and accountability mechanisms have to be established. It should be noted that careful implementation of decentralisation rests on breadth, depth, continuity, nature of special implementation machinery, and the degree of acceptability or opposition which it will generate at the center and local levels. Finally, decentralisation is about deepening democracy at the local level by integrating citizens in the democratic system. Establishing democracy and good governance has to be done within a clear national policy framework on service delivery rather than on foreign actors only.

\section{References}

Alvarez Angel 1998 Venezuelan Local and National Elections, 1958-1995.In Dietz Henry and Gil Shidlo eds. Urban Elections in Democratic Latin America Wilmington: Scholarly Resources, Inc.

Ayee Joseph R. A. (1994) An Anatomy of Public Policy Implementation: Case of Decentralisation Policies in Ghana Avebury Barkan J. and Chege Michael 1989.Decentralizing the State: District Focus and the Politics of Reallocation in Kenya, Journal of Modern African Studies 27(3) pp. 401-431.

Berry Jeffrey M., Kent E. Portney, and Ken Thomas (1993) Rebirth of Urban Democracy. Washington: Brookings Institution. Blaug Ricardo 1995, A Talk? The New Deliberative Theories of Democracy Rohit Lekhi (ed.) The State of the Academy: New Reflections on Political Studies Network Press, pp. 52-59.

Boeninger Edgardo 1991 Governance and Development: Issues and Constraints. Proceedings of the World Bank Annual Conference on Development Economics, pp. 267-287.

Bullock A. et. al. (1977) The Fontana Dictionary of Modern Thought (Fontana Press), 2nd ed.

Burki Shahid Javed, Perry Guillermo E., and Dillinger William 1999. Beyond the Centre: Decentralizing the State Washington D.C.: World Bank

Conyers D. 1990. Centralisation and Development Planning: A Comparative Perspective, in P. de Valk and K. H. Wekwete (eds.) Decentralizing for Participatory Planning? Comparing the Experiences of Zimbabwe and Other Anglophone Countries in Eastern and Southern Africa, Gower Publishing Company Ltd. Chapter Two, pp. 15-34. 
Diamond Larry 1997 Introduction: In Search of Consolidation, in Larry Diamond, Marc F. Platter, Yun-han Chu, and HungMao Tien (eds.) Consolidating the Third Wave Democracies. Baltimore: The Johns Hopkins University Press.

Doornbos M. 1999. Globalisation, the State and Other Actors: Revisiting State Autonomy, in J. Martinussen (ed.) External and Internal Constraints on Policy-making: How Autonomous are the States? Occasional Paper No. 20, Institute of Development Studies, Roskilde.

Hirschman Alberto (1970) Exit, Voice and Loyalty Cambridge, MA: Harvard University Press.

Kauzya John-Mary 2007 Political Decentralisation in Africa: Experiences of Uganda, Rwanda and South Africa, Discussion Paper, December.

Kiyaga-Nsubuga John and Olum Yasin 2009 Local Governance and Local Democracy in Uganda, in Commonwealth Journal of Local Governance, (2) pp. 26-43.

Kjaer A. M. and Olum Y. 2008 From Confrontation to Acquiescence? The Role of Civil Society and the Media. In the 2006 Elections in Uganda, In Kiiza J., Sabiti M. and Lise R. (eds.) Electoral Democracy in Uganda: Understanding the Institutional Processes and Outcomes of the 2006 Multiparty Elections Kampala: Fountain.

Leonard David(1982 Analyzing the Organisational Requirements for Serving the Rural Poor In David Leonard and Dale Rogers Marshall (eds.) Institutions of Rural Development for the Poor. Berkeley: Institute of International Studies.

Lisk F. A. N. (ed.) (1985) Popular Participation in Planning for Basic Needs ILO, Gower.

Lisk F. A. N. 1981 Popular Participation in Basic Needs Oriented Development Planning, Labour and Society, Vol(6)1.

Litvack Jennie, Ahmad Junaid, and Bird Richard 1998 Rethinking Decentralisation in Developing Countries World Bank.

Martinez-Vazquez and McNab Robert 1997 Fiscal Decentralisation, Economic Growth, and Democratic Governance, Working Paper 97-7:George State University, Andrew Young School of Policy Studies.

Mutahaba G. R. 1991 Organisation for Local Governance: Searching for an Appropriate Local Level Institutional Framework in Tanzania. In Richard C. Crook and Alf Morten Jerve (eds.) Government and Participation: Institutional Development, Decentralisation and Democracy in the Third World (Bergen: CMI), pp. 69-92.

Newton Karl A. 1995 Globalisation, the Nation State and the Rewriting of Democracy, in Rohit Lekhi (ed.) The State of the Academy: New Reflections on Political Studies. Network Press: pp. 104-109.

Nickson Andrew (1995) Local Governments in Latin America Boulder and London: Lynne Reinner Publishers.

Nkunika Adam I. Z. 1987. The Role of Popular Participation in Programs of Social Development, Journal of Social Development in Africa, No2.

Olum Yasin 2010 Participatory Budgeting in Decentralized Local Governments in Uganda The Uganda Journal of Management and Public Policy Studies. Vol (1)1 pp. 98-119.

Olum Yasin A. A. 1989 Political Participation as a Strategy for Achieving Development Administration: A Case Study of Resistance Committees/Councils in Uganda, being a MA (Econ.) dissertation University of Manchester,

Pearse A. and Stiefel M. (1979) Inquiry into Participation: A Research Approach. Geneva: UNRISD.

Pollitt Christopher 2007 Towards a New Public Administration Theory: Some Comments on Jocelyne Bourgon's $5^{\text {th }}$ Braibant Lecture IIAS International Review of Administrative Sciences 73 (1), pp. 37-41.

Prah Kwesi Kwaa 2004 African Wars and Ethic Conflicts - Rebuilding Failed States, being a Background Paper for Human Development Report (HDR) Office, United Nations Development Programme.

Przeworski Adam 1995 Comment on The Impact of Constitutions on Economic Performance, by Elster. Proceedings of the Annual World Bank Conference on Development Economics 1994. Washington D.C.

Putnam Robert D. (1993) Making Democracy Work: Civic Traditions in Modern Italy Princeton N.J.: Princeton Uni. Press.

Rhodes R. A. W. 1995 The Institutional Approach, in David Marsh and Gerry Stoker (eds.) (1995) Theory and Methods in Political Science .Macmillan Press Ltd.

Rondinelli D. A. 1982 The Dilemma of Development Administration: Complexity and Uncertainty in Control-Oriented Bureaucracies, World Politics, Vol (35) pp. 52-65.

Saasa Oliver S. 2000 State Administration in Zambia: The Case of Decentralisation. Sweden: Nordic Africa Institute, Sept..

Shapiro Ian (2003) The State of Democratic Theory Princeton and Oxford: Princeton University Press.

Smith B. C. (1985) Decentralisation: The Territorial Dimension of the State London: George Allen and Unwin.

Steffensen Jesper, Tidemand Per, Naitore Harriet, Ssewankambo Emmanuel, and Mwaipopo Eke 2004 Final Synthesis Report: A Comparative Analysis of Decentralisation in Kenya, Tanzania and Uganda (NCG), August.

Uphoff Norman 1985 Local Institutions and Decentralisation for DevelopmentIin Hasnat Abdul Hye (ed.) Decentralisation, Local Government Institutions and Resource Mobilisation Camilla, Bangladesh: Bangladesh Academy for Rural Development, pp. 43-77. 